\title{
Production of bio-fertilizer from microwave vacuum pyrolysis of waste palm shell for cultivation of oyster mushroom (Pleurotus ostreatus)
}

\author{
Wai Lun $\mathrm{Nam}^{1}$, Man Huan $\mathrm{Su}^{1}$, Xue Yee Phang ${ }^{1}$, Min Yee Chong ${ }^{1}$, Rock Keey Liew ${ }^{1}$, Nyuk \\ Ling $\mathrm{Ma}^{2}$, and Su Shiung Lam ${ }^{1, *}$ \\ ${ }^{1}$ Pyrolysis Technology Research Group, Eastern Corridor Renewable Energy Group, School of Ocean \\ Engineering, Universiti Malaysia Terengganu, 21030 Kuala Nerus, Terengganu, Malaysia \\ ${ }^{2}$ School of Fundamental Science, Universiti Malaysia Terengganu, 21030 Kuala Nerus, Terengganu, \\ Malaysia
}

\begin{abstract}
Microwave vacuum pyrolysis of waste palm shell (WPS) was performed to produce biochar, which was then tested as bio-fertilizer in growing Oyster mushroom (Pleurotus ostreatus). The pyrolysis approach generated a biochar containing a highly porous structure with a high BET surface area (up to $1250 \mathrm{~m}^{2} / \mathrm{g}$ ) and a low moisture content $(\leq 10 \mathrm{wt} \%)$, exhibiting desirable adsorption properties to be used as bio-fertilizer since it can act as a housing that provides many sites on which living microorganisms (mycelium or plant-growth promoting bacteria) and organic nutrients can be attached or adsorbed onto. This could in turn stimulate plant growth by increasing the availability and supply of nutrients to the targeted host plant. The results from growing Oyster mushroom using the biochar record an impressive growth rate and a monthly production of up to about $550 \mathrm{~g}$ of mushroom. The shorter time for mycelium growth on whole baglog (30 days) and the highest yield of Oyster mushroom $(550 \mathrm{~g})$ was obtained from the cultivation medium added with $20 \mathrm{~g}$ of biochar. Our results demonstrate that the biochar-based bio-fertilizer produce from microwave vacuum pyrolysis of WPS show exceptional promise as an alternative growing substrate for mushroom cultivation.
\end{abstract}

\section{Introduction}

Malaysia is one of the global leading palm oil producer which have palm oil plantation covering $80 \%$ of the agricultural area in Malaysia. The production of crude palm oil is approaching 20 million tonnes yearly [1] in order to satisfy the world demand on oil and fats [2]. As a result, there are also huge amount of by-products such as mesocarp fiber (MF), palm kernel shell (PKS), and empty fruit bunch (EFB) being generated as oil palm wastes and they become a disposal problem for palm oil industry.

* Corresponding author: lam@umt.edu.my 
Microwave vacuum pyrolysis (MVP) is an innovative pyrolysis approach recently developed to transform the oil palm wastes into potentially useful products such as biochar, bio-oil and biogas. The pyrolysis process is performed using microwave heating in vacuum environment. Biochar is a main product derived from MVP after the evaporation of volatile matter and moisture content from the feedstocks. It is a carbon dense material with high porosity and large surface area. The high carbon content in biochar provides a long term storage solution because of its stable carbon bonds [3]. Biochar gives many environment benefits such as improving water quality by retaining agrochemicals in soils, mitigating climate change by storing the carbon in soil, and serving as a simple way to manage agricultural waste [4]. Its good adsorption property could contribute to soil amendment by enhancing the nutrients and water retention, and consequently boost up the growth rate and product yield of crops [5].

Mushroom possesses an antioxidant property which helps to reduce the oxidative damage in human body and provides protection against disease such as cancer and cardiovascular disease [6]. The high amount of carbohydrate, protein, multivitamins (i.e. vitamin B, C, D) and minerals (i.e. iron, calcium, potassium) present in the mushroom has made it a target food source for health-conscious consumers [7]. In particular, oyster mushroom (Pleurotus ostreatus) represents a favourite mushroom that is suitable to be grown in Malaysia. It adapts to moderate temperature and thus it can be cultivated in the lowlands [8]. The low production cost of oyster mushroom allows it to be supplied to consumers all around the year [6]. Due to the nutritional and medical values of mushroom, the demand for the mushroom in Malaysia is about 50 tonnes/day [8]. However, the average production of mushroom (e.g. $50 \mathrm{~kg}$ /day) is only enough to supply to the local consumers instead of exporting to other country [8]. In order to increase the product yield and quality of mushroom, it is hypothesized that biochar can act as an enhancer to boost up the growth of mushroom. Thus, this study was performed to produce biochar from microwave vacuum pyrolysis and then apply the biochar produced as bio-fertilizer for mushroom cultivation.

\section{Materials and methods}

\subsection{Collection and pre-treatment of waste palm shell}

Waste palm shell (WPS) was collected from TDM Plantation SDN BHD located in Sungai Tong, Setiu, Terengganu. The waste was dried in oven at $110^{\circ} \mathrm{C}$ for 24 hours in order to remove the moisture content.

\subsection{Production of biochar from microwave vacuum pyrolysis of WPS}

Microwave vacuum pyrolysis was performed to produce biochar. It has been reported that higher surface area and pore volume was produced from microwave pyrolysis compared to conventional heating [5]. Figure 1 shows the schematic diagram of the microwave vacuum pyrolysis. A $2.45 \mathrm{GHz}$ (model: Samsung) microwave oven was modified to generate microwave radiation as heating source. $300 \mathrm{~g}$ of WPS was filled into a 1 Litre quartz reactor with $100 \mathrm{~mm}$ length and $123 \mathrm{~mm}$ diameter and then placed into a microwave oven to perform microwave vacuum pyrolysis. Air mixtures inside the oven were removed to create a vacuum condition before the start of pyrolysis experiments. The microwave power of oven was then set at $700 \mathrm{~W}$ and then the heating and pyrolysis were performed for 1 hour to transform the WPS into biochar. 


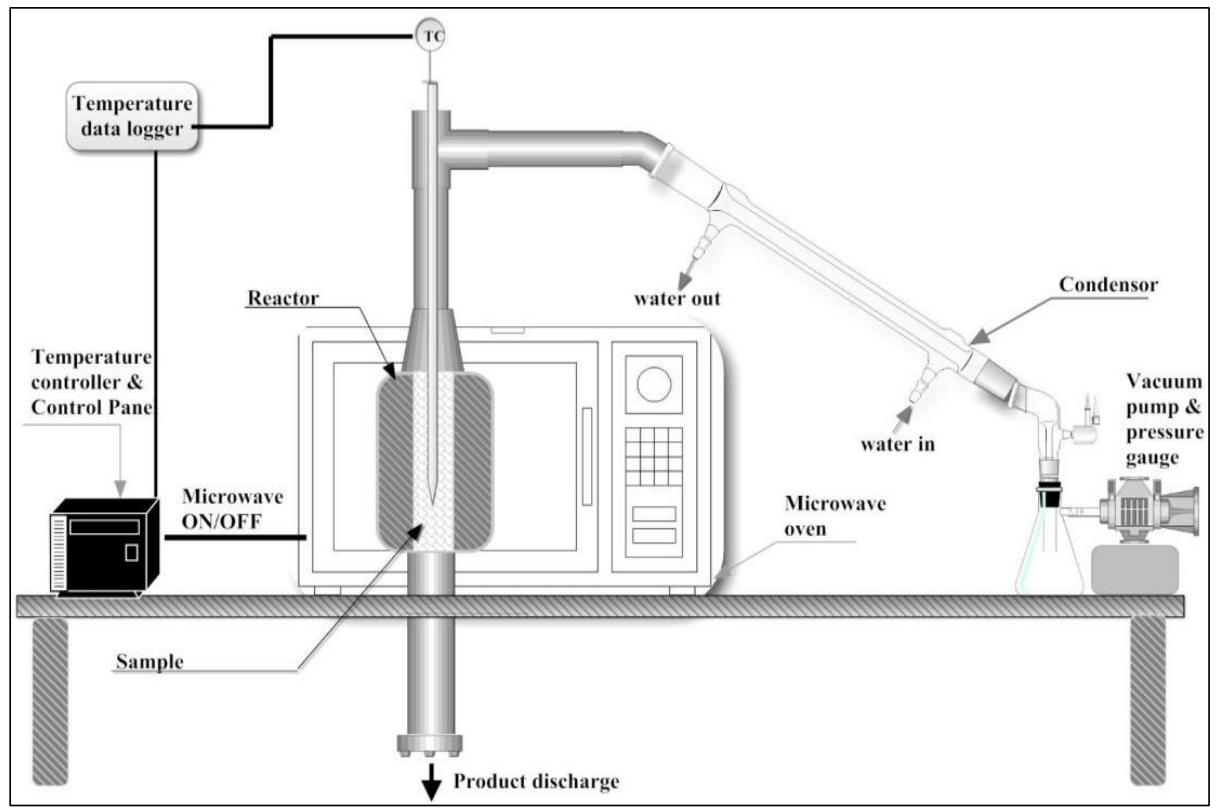

Fig. 1. Schematic diagram of microwave vacuum pyrolysis.

\subsection{Characterization of waste palm shell and biochar}

Different analysis was conducted to determine the chemical composition and physical surface structure of the WPS and biochar. Thermo-gravimetric Analysis (TGA) and CHNS elemental analysis were performed to quantify the proximate contents (moisture content, volatile matter, fixed carbon and ash) and elemental content (carbon, hydrogen, nitrogen and sulphur) of the WPS and biochar [9]. The surface morphology of biochar was examined by Scanning Electron Microscopy (SEM) and multipoint Brunauer, Emmett and Teller (BET) to determine the porous characteristics (i.e. surface area, pore width, and total pore volume).

\subsection{Media formulation for mushroom cultivation}

The biochar produced was ground into smaller pieces $(2-4 \mathrm{~mm})$ using a grinder and then it was mixed with other ingredients to form the mushroom cultivation medium. Different amounts of biochar (10 g, $20 \mathrm{~g}$, and $30 \mathrm{~g})$ were mixed thoroughly with rice bran, calcium carbonate, and sawdust to produce three different sets of cultivation medium as shown in Table 1. The lignocellulosic content of the rice bran and sawdust is a suitable substrate to provide nutrient for mushroom growth [10] and calcium carbonate is used to balance the $\mathrm{pH}$ of the mixture. Water was then added to the mixture to increase moisture content inside the mixture [11]. A polyethylene cylindrical bag was used to make a baglog that was then filled with $1 \mathrm{~kg}$ of the cultivation medium, then the baglog was sealed using PVC neck with cover. The bag was then sterilised at $121^{\circ} \mathrm{C}$ for 1 hour in the autoclave. After sterilisation, the baglogs were cooled to room temperature and then the oyster mushroom spawn was injected into the baglogs. The baglogs were then placed in a storage house for further observation. The experiments were performed in triplicates to improve the accuracy and 
reproducibility of the data collected. Analysis was done with the observation and measurement of the growth of mycelium on a weekly basis and the yield of mushroom over a period of 35 days.

Table 1. Media formulation for mushroom cultivation.

\begin{tabular}{|c|c|c|c|c|}
\hline \multirow{2}{*}{ Ingredient } & \multicolumn{4}{|c|}{ Media Formulation } \\
\cline { 2 - 5 } & $\begin{array}{c}\text { Control } \\
(\mathbf{g})\end{array}$ & $\begin{array}{c}\text { Mixture 1 } \\
(\mathbf{g})\end{array}$ & $\begin{array}{c}\text { Mixture 2 } \\
(\mathbf{g})\end{array}$ & $\begin{array}{c}\text { Mixture 3 } \\
(\mathbf{g})\end{array}$ \\
\hline Biochar & - & 10 & 20 & 30 \\
\hline Rice bran & 87 & 86 & 85 & 84 \\
\hline Calcium carbonate & 12 & 12 & 12 & 12 \\
\hline Sawdust & 901 & 892 & 883 & 874 \\
\hline Mushroom seed & $1 / 10$ & $1 / 10$ & $1 / 10$ & $1 / 10$ \\
\hline
\end{tabular}

\subsection{Determination of mycelium growth rate and yield of Oyster mushroom}

The cultivation period was set in one month for mycelium growth. Observation was performed on the growth of mycelium every week. The analysis on mycelium growth rate was based on the length of the mycelium grown along the baglog. The length of the mycelium growth was measured and expressed as a percentage of total height of mycelium colonized the baglog. At the 35-days harvest period, the mushrooms were harvested. The total weight of mushroom yield (fresh mature mushroom harvested) was determined and average mushroom yield was calculated. The harvesting time could be different for each baglog depending on the mushroom growth [11].

\section{Results and discussion}

\subsection{Characterization of waste palm shell (WPS) and biochar}

Table 2 shows the elemental and proximate content of WPS and the biochar produced by microwave vacuum pyrolysis. The results showed that WPS consisted mainly of carbon $(50.5 \%)$ with low contents of hydrogen $(7.0 \%)$ and nitrogen $(3.1 \%)$. Proximate analysis showed that WPS was dominated by volatile matter $(66.5 \%)$ followed by fixed carbon $(27.6 \%)$ with a small amount of moisture content (1.9\%) and ash (4\%).

After the pyrolysis process, the biochar produced was found to have a high content of fixed carbon $(83 \%)$, indicating the production of a carbon rich material. The biochar contained a low amount of volatile matter $(9.4 \%)$, possibly due to the evaporation of volatile chemical derived from pyrolysis decomposition occurred at high temperature. 
Table 2. Elemental and proximate content (wt\%) of WPS and biochar.

\begin{tabular}{|c|c|c|}
\hline \multirow{2}{*}{ Elemental Content } & \multicolumn{2}{|c|}{ Weight (wt\%) } \\
\cline { 2 - 3 } & WPS $^{\mathbf{a}}$ & Biochar \\
\hline Carbon & 50.5 & 70.3 \\
\hline Hydrogen & 7.0 & 3.6 \\
\hline Nitrogen & 3.1 & 0.6 \\
\hline Oxygen $^{\mathrm{b}}$ & 39.4 & 25.5 \\
\hline Sulphur $^{\mathrm{c}}$ & 0.0 & 0.0 \\
\hline Proximate Content $^{\mathrm{N}}$ & & \\
\hline Moisture & 1.9 & 4.0 \\
\hline Volatile Matter $^{\mathrm{F}}$ & 66.5 & 9.4 \\
\hline Fixed Carbon $^{\mathrm{d}}$ & 27.6 & 82.6 \\
\hline Ash $^{\mathrm{e}}$ & 4.0 & 4.0 \\
\hline
\end{tabular}

${ }^{a}$ WPS - Waste Palm Shell.

${ }^{b}$ Determined by mass difference.

'Sulphur content is not detectable by the minimum detection limit of the CHNS analyser $(<0.05 \mathrm{wt} \%)$ and thus it is assumed to be $0 \mathrm{wt} \%$ in calculation.

${ }^{\mathrm{d}}$ Calculated by mass difference (i.e. Fixed carbon $=100 \mathrm{wt} \%-\mathrm{wt} \%$ of volatile matter - ash).

${ }^{\mathrm{e}}$ Obtained by combustion at $950^{\circ} \mathrm{C}$ with $10 \mathrm{~min}$ of holding time.

\subsection{Surface morphology of waste palm shell and biochar}

Figure 2 demonstrates the SEM micrograph of biochar obtained from our microwave vacuum pyrolysis approach. Pores were observed on the surface of the biochar compared to the WPS which was non-porous and had a rough surface. This indicates that the microwave vacuum pyrolysis has caused the formation of a highly porous structure within the biochar. The highly porous structure suggests that the biochar could be utilised as an adsorption media.

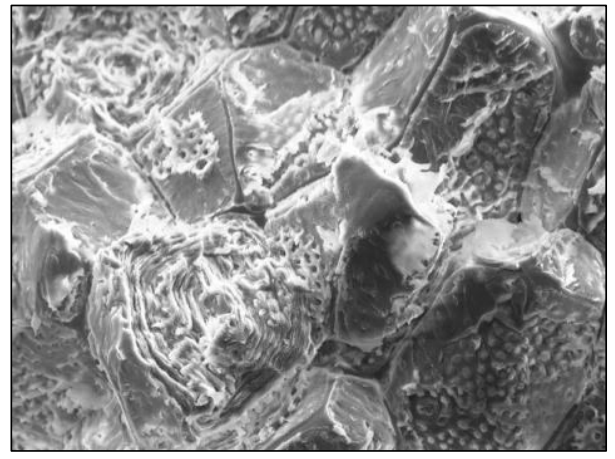

WPS (Before)

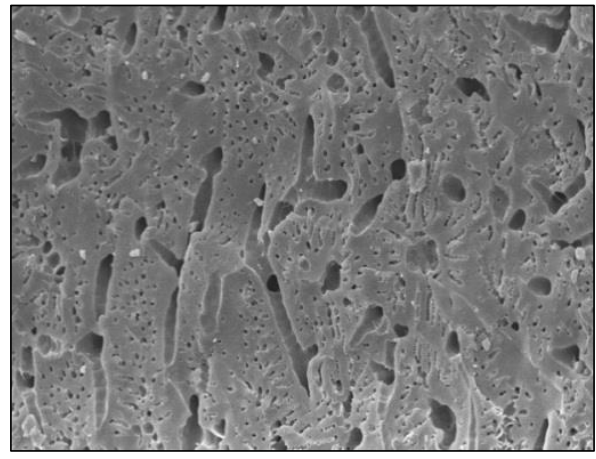

Biochar (After)

Fig. 2. SEM micrograph of WPS and biochar.

\section{3 $\mathrm{N}_{2}$ adsorption-desorption isotherm and porous characteristics of biochar}

Figure 3 shows the $\mathrm{N}_{2}$ adsorption-desorption isotherm of the biochar produced and the porous characteristics are presented in Table 3. According to IUPAC classification, the isotherm curve of the biochar showed a Type IV isotherm which indicates the presence of mesopores with a pore size from $2 \mathrm{~nm}$ to $50 \mathrm{~nm}$. High surface area was detected for the biochar $\left(1225 \mathrm{~m}^{2} / \mathrm{g}\right)$ and this indicates that it has high potential to be used as nutrient 
adsorbent. Thus, the biochar was tested for its use as a supporting ingredient in mushroom cultivation due to the presence of porous structure and good adsorption capacity

Table 3. Porous characteristics of biochar.

\begin{tabular}{|c|c|}
\hline Porous Characterisstics & Biochar \\
\hline Surface area & $1225 \mathrm{~m}^{2} / \mathrm{g}$ \\
\hline Total pore volume & $0.75 \mathrm{~m}^{3} / \mathrm{g}$ \\
\hline Pore size & $3.2 \mathrm{~nm}$ \\
\hline
\end{tabular}

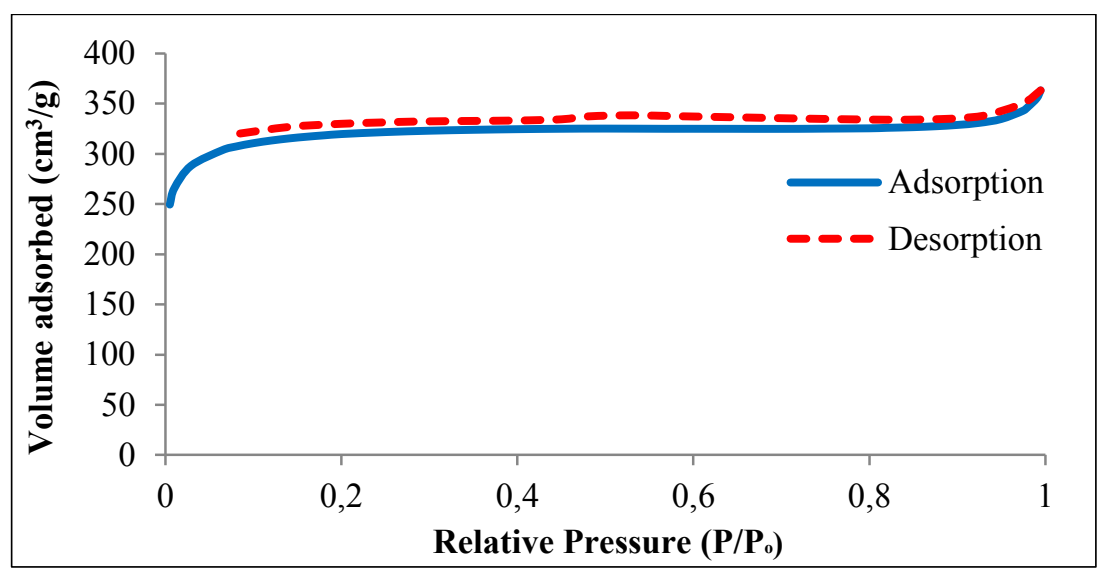

Fig. 3. $\mathrm{N}_{2}$ Adsorption-Desorption Isotherm of biochar.

\subsection{Biochar as bio-fertilizer for mushroom cultivation}

The highly porous structure with a high BET surface area (up to $1225 \mathrm{~m}^{2} / \mathrm{g}$ ) of the biochar produced provided many sites to absorb and retain the desirable nutrient for the mycelium to grow. Mycelium is a vegetative growth in fungi and appears as white microscopic threads filaments (FAO, 2009). The surface of the biochar was fully distributed with pores which support its potential use as a bio-fertilizer. It was observed that mycelium was fully grown in 28-30 days within the baglog added with biochar compared to that observed in the baglog without the biochar ( $30-35$ days).

Table 4 shows the different growth rates of the mycelium of Oyster mushroom observed from the baglog added with different amounts of biochar. It showed that the baglog added with biochar had a faster mycelium growth rate meanwhile the control showed the slowest growth rate. This suggests that the biochar added to the mushroom cultivation medium enhanced the mycelium growth.

The mushroom yields are based on weight of the Oyster mushroom harvested from each of the baglog in one month. As shown in Table 4, mixture 2 records the highest yield, producing $550 \mathrm{~g}$ of mushroom. It showed an impressively product yield as the total yield of mushroom is more than $50 \%$ compared with the control baglog. The porous structure of the biochar had contributed a large adsorption surface area for water and nutrient retention. The increased level of nutrient availability was likely to have enhanced the growth of mycelium. The strong water-holding capacity of the biochar could also supply enough moisture during fruiting stage of the mushroom, thus reducing the mortality of young mushroom yield due to the water shortage [12]. Therefore, our results showed that biochar can be a potential biofertilizer to enhance the mycelium growth and mushroom yield. 
Table 4. Mycelium growth rate on weekly basis.

\begin{tabular}{|c|c|c|c|c|}
\hline \multirow{2}{*}{$\begin{array}{c}\text { Time } \\
\text { (day) }\end{array}$} & \multicolumn{4}{|c|}{ Mycelium Growth (Height of mycelium colonized the baglog) } \\
\cline { 2 - 5 } & Control & Mixture 1 & Mixture 2 & Mixture 3 \\
\hline 0 & $\begin{array}{c}\text { Innoculum on } \\
\text { the surface }\end{array}$ & $\begin{array}{c}\text { Innoculum on } \\
\text { the surface }\end{array}$ & $\begin{array}{c}\text { Innoculum on } \\
\text { the surface }\end{array}$ & $\begin{array}{c}\text { Innoculum on } \\
\text { the surface }\end{array}$ \\
\hline 7 & $\begin{array}{c}\text { Mycelium fills } \\
25 \% \text { baglog }\end{array}$ & $\begin{array}{c}\text { Mycelium fills } \\
25 \% \text { baglog }\end{array}$ & $\begin{array}{c}\text { Mycelium fills } \\
\text { almost } 50 \% \\
\text { baglog }\end{array}$ & $\begin{array}{c}\text { Mycelium fills } \\
25 \% \text { baglog }\end{array}$ \\
\hline 14 & $\begin{array}{c}\text { Mycelium fills }> \\
25 \% \text { baglog }\end{array}$ & $\begin{array}{c}\text { Mycelium fills } \\
50 \% \text { baglog }\end{array}$ & $\begin{array}{c}\text { Mycelium fills } \\
50 \% \text { baglog }\end{array}$ & $\begin{array}{c}\text { Mycelium fills } \\
\text { almost } 50 \% \\
\text { baglog }\end{array}$ \\
\hline 21 & $\begin{array}{c}\text { Mycelium fills } \\
50 \% \text { baglog }\end{array}$ & $\begin{array}{c}\text { Mycelium fills } \\
75 \% \text { baglog }\end{array}$ & $\begin{array}{c}\text { Mycelium fills } \\
\text { whole baglog }\end{array}$ & $\begin{array}{c}\text { Mycelium fills } \\
75 \% \text { baglog }\end{array}$ \\
\hline 28 & $\begin{array}{c}\text { Mycelium fills } \\
75 \% \text { baglog }\end{array}$ & $\begin{array}{c}\text { Mycelium fills } \\
\text { whole baglog }\end{array}$ & $\begin{array}{c}\text { Mushroom start } \\
\text { to grow }\end{array}$ & $\begin{array}{c}\text { Mycelium fills }> \\
75 \% \text { baglog }\end{array}$ \\
\hline 35 & $\begin{array}{c}\text { Mycelium fills } \\
\text { whole baglog }\end{array}$ & $\begin{array}{c}\text { Mushroom start } \\
\text { to grow }\end{array}$ & $\begin{array}{c}\text { Mushroom start } \\
\text { to grow }\end{array}$ & $\begin{array}{c}\text { Mycelium fills } \\
\text { whole baglog }\end{array}$ \\
\hline
\end{tabular}

Table 5. Weight of Oyster mushroom harvested in one month.

\begin{tabular}{|c|c|c|c|c|}
\hline \multirow{2}{*}{ Baglog } & \multicolumn{3}{|c|}{ Harvest ( g/month) } & \multirow{2}{*}{$\begin{array}{c}\text { Average } \\
\text { (g/month) }\end{array}$} \\
\cline { 2 - 4 } & Set 1 & Set 2 & Set 3 & \\
\hline Control & 199.8 & 205.4 & 290.8 & 232.0 \\
\hline Mixture 1 & 466.3 & 461.8 & 513.1 & 480.4 \\
\hline Mixture 2 & 563.5 & 551.7 & 534.8 & 550.0 \\
\hline Mixture 3 & 449.6 & 498.3 & 404.8 & 450.9 \\
\hline
\end{tabular}

\section{Conclusion}

The high lignocellulose content and carbon content of WPS indicates its suitability as a precursor for production of biochar. Microwave vacuum pyrolysis converted WPS into a biochar with high surface area and pore volume which contributed a strong adsorption capacity on water and nutrient uptake. The biochar based bio-fertiliser enhanced the mycelium growth and the yield of oyster mushroom. Mixture 2 with $20 \mathrm{~g}$ of biochar showed the fastest mycelium growth (21 days to fully filled the baglog) and produced highest yield of Oyster mushroom (550 g/month) for the first harvest after 1 month. This indicates the huge potential of the biochar to be used as a bio-fertilizer for Oyster mushroom cultivation.

\section{References}

1. MPOB, Production of Crude Palm Oil for the month of December 2016, (2016)

2. M.F. Awalludin, O. Sulaiman, R. Hashim, W.N.A.W. Nadhari, Renew. Sust. Energ. Rev. 50 (2015)

3. N.D. Van Beilen, Inquiries Jour. 8 (2016)

4. I.B. Initiative, Environmental Benefits of Biochar (2017) 
5. J. Li, J. Dai, G. Liu, H. Zhang, Z. Gao, J. Fu, Y. He, Y. Huang, Biomass Bioenerg. 94 (2016)

6. A.N.M. Rashidi, T.A. Yang, IJAST, Engineering and Information Technology, 6 (2016)

7. B.A. Wani, R. Bodha, A. Wani, J. Med. Plants Res. 4 (2010)

8. M.Z.M. Amin, A. Harun, M. Wahab, ETMR, 9b (2014)

9. S.S. Lam, R.K. Liew, X.Y. Lim, F.N. Ani, A. Jusoh, Int. Biodeter. Biodegr. 113 (2016)

10. Y. Sibel, C.Y. U“ Mit, D.G. Engin, T. Ali, Process Biochemistr. 38, 301-306 (2002)

11. L. Marlina, S. Sukotjo, S. Marsudi, Procedia Chem. 16 (2015)

12. W. Yang, F. Guo, Z. Wan, Saudi J. Biol. Sci. 20 (2013) 